УДК: 616.12-005.4:616.132.2-008.811.7

\title{
Причини та наслідки екстреної конверсії на допоміжний штучний кровообіг під час коронарного шунтування у хворих з ішемічною хворобою серця
}

\author{
Руденко А. В., Журба О. О.
}

ДУ «Національний інститут серцево-судинної хірургії імені М. М. Амосова НАМН» (Київ)

\begin{abstract}
Екстрена конверсія на ШК під час КШ на працюючому серці значно погіршує безпосередні результати реваскуляризації міокарда. Метою цього дослідження є огляд причин та наслідків цих випадків за результатами ретроспективного аналізу історій хвороби 4068 пацієнтів. Встановлено, що у хворих із застосуванням ШК спостерігається достовірне збільшення частоти всіх післяопераційних ускладнень, а при екстреному ШК зростає післяопераційна летальність. Причинами екстреної конверсії були гемодинамічна нестабільність, елевація сегмента ST та порушення ритму. Ці інтраопераційні ускладнення виявлялися і в інших хворих, але вони були усунені без застосування ШК. Вважаємо, що ускладнення під час операції мають подібні провокуючі фактори, що слід ураховувати при визначенні предикторів їх розвитку.
\end{abstract}

Ключові слова: коронарне шунтування, працююче серие, штучний кровообіг, екстрена конверсія, безпосередні результати, інтраопераційні ускладнення.

За даними глобальних епідеміологічних досліджень, ішемічна хвороба серця (IXC) посідає одне 3 провідних місць у структурі смертності сучасного людства, яка з 2005 по 2015 рр. зросла на 16,6\% [10]. За даними Н. О. Теренда (2016), прогнозована поширеність IXC до 2025 року зросте на $63,5 \%$, а первинна захворюваність - на 61,1\% [4]. У багатьох випадках досягти стійкого лікувального ефекту у хворих на IXC можливо тільки шляхом реваскуляризації, а застосування фармакологічних засобів має значення тільки в якості додаткової підтримуючої терапії [5]. У Європі кількість центрів інвазивної кардіології сягає 2,4 тис., а в Україні їх лише 24, і вони виконують біля 21 тис. втручань на рік із приводу IXC при розрахунковій потребі майже 200 тис. на рік [1]. Тому подальший розвиток кардіохірургії в нашій державі потребує негайних організаційних та фінансово-економічних заходів з боку держави. 3 іншого боку, актуальним $є$ подальший розвиток заходів з удосконалення техніки кардіохірургічних втручань для оптимізації їх результатів.

Найбільш поширеними технологіями КШ на цей час є КШ на працюючому серці, КШ із застосуванням штучного кровообігу (ШК) з кардіоплегією та КШ на працюючому серці в умовах допоміжного ШК. Останнім часом все більша частина кардіоцентрів віддає перевагу виконанню КШ на працюючому серці, що має не тільки медичне значення, а й більш доцільне в аспекті зниження матеріальних втрат на лікування [2, $3,9,12]$. На жаль, в окремих випадках під час КШ на працюючому серці виникають інтраопераційні ускладнення та/або технічні труднощі, які потребують засто- сування екстреного підключення ШК. Частота таких випадків варіює від $2 \%$ до $22 \%$, а їх результати значно гірші, ніж КШ без ШК або КШ з плановим призначенням допоміжного ШК [6, 11-13]. Тому актуальним питанням сучасної кардіохірургії $€$ розробка методів попередження цих випадків.

Мета дослідження - оптимізація доопераційного планування застосування ШК для попередження екстреної конверсії під час КШ у хворих з IXC. У цій публікації наведено результати фрагмента дослідження, а саме - аналіз причин та наслідків екстреного ШК при КШ на працюючому серці.

Матеріали та методи. Дослідження виконано на базі відділення хірургічного лікування IXC у Національному інституті серцево-судинної хірургії імені М. М. Амосова. Здійснено ректроспективний аналіз історій хвороби 4068 пацієнтів, яким виконано ізольоване КШ на працюючому серці у 2009-2013 pр., у тому числі в $110(2,7 \%)$ випадках - із запланованим допоміжним ШК, а у $82(2,0 \%)$ хворих під час оперативного втручання здійснено екстрену конверсію на допоміжний ШК у зв'язку з інтраопераційними ускладненнями. Проаналізовано клініко-анамнестичні дані (стать, вік, особливості супутньої патології та основного захворювання, перенесені кардіальні втручання, показники ехокардіоскопії, перебіг операції та раннього післяопераційного періоду). Отримані дані оброблено із застосуванням методів описової статистики, порівняння частоти якісних показників із застосуванням таблиць спряженості з визначенням критерію $\chi^{2}$. Відмінності вважали значущими при ймовірності нульової гіпоте- 
Руденко А. В. / Причини та наслідки екстреної конверсії на допоміжний штучний кровообіг під час...

Таблиця 1

Безпосередні результати КШ залежно від застосування ШК

\begin{tabular}{lcccc} 
П/о ускладнення & $\begin{array}{c}\text { КШ без ШК } \\
(\mathbf{n = 3 8 7 6 )}\end{array}$ & $\begin{array}{c}\text { КШ з плановим ШК } \\
(\mathbf{n = 1 1 0 )}\end{array}$ & $\begin{array}{c}\text { КШ з екстреним ШК } \\
(\mathbf{n = 8 2 )}\end{array}$ & Разом \\
\hline СН & $155(4,0 \%)$ & $10(9,1 \%)^{1,2}$ & $19(23,2 \%)^{1}$ & $184(4,5 \%)$ \\
\hline ГПМК & $48(1,2 \%)$ & $2(1,8 \%)$ & $2(2,4 \%)$ & $52(1,3 \%)$ \\
\hline ДН & $116(3,0 \%)$ & $8(7,3 \%)^{1}$ & $11(13,4 \%)^{1}$ & $45(3,3 \%)$ \\
\hline Ниркова недостатність & $24(0,6 \%)$ & $3(2,7 \%)^{1}$ & $4(4,9 \%)^{1}$ & $31(0,8 \%)$ \\
\hline Миготлива аритмія & $701(18,1 \%)$ & $23(20,9 \%)$ & $18(22,0 \%)$ & $742(18,2 \%)$ \\
\hline ІМ & $10(0,3 \%)$ & - & $4(4,9 \%)^{1}$ & $14(0,34 \%)$ \\
\hline Інфекційні ускладнення & $43(1,1 \%)$ & $4(3,6 \%)^{1}$ & $8(9,8 \%)^{1}$ & $55(1,4 \%)$ \\
\hline Померло протягом 30 діб & $19(0,5 \%)$ & $2(2,4 \%)$ & $6(7,3 \%)^{1}$ & $27(0,7 \%)$
\end{tabular}

Примітки: 1 - достовірні розбіжності за критерієм $\chi^{2}(\mathrm{p}<0,05)$ з групою КШ без застосування ШК; 2 - достовірні розбіжності за критерієм $\chi^{2}(\mathrm{p}<0,05)$ з групою КШ з плановим ШК

зи менше $5 \%(\mathrm{p}<0,05)$. Для розрахунків використано пакет статистичних програм IBM SPSS Statistics 21.0.

Результати та обговорення. Протягом 2009-2013 pp. серцева недостатність $(\mathrm{CH})$ із розвитком синдрому малого викиду та/або з необхідністю тривалої інотропної підтримки ускладнила післяопераційній період у $4,5 \%$ хворих, у тому числі у 4,0\% пацієнтів, оперованих без застосування ШК, у 9,1\% хворих із плановим ШК ( $\mathrm{p}=0,016$ порівняно 3 групою КШ без застосування ШК за критерієм $\chi^{2}$ ) та у $23,2 \%$ хворих з екстреним ШК ( $<<0,001$ порівняно з групою КШ без застосування ШК та $\mathrm{p}=0,013$ порівняно $з$ групою з плановим ШК). Гострі порушення мозкового кровообігу (ГПМК) ускладнили післяопераційний період у 1,2\% хворих, яким виконано КШ без ШК, у 1,8\% хворих із плановим ШК (p>0,05 порівняно з групою КШ без застосування ШК) та 2,4\% у хворих з екстреним ШК (p>0,05 порівняно з групою КШ без застосування ШК та порівняно з групою з плановим ШК) (табл. 1).

Дихальну недостатність (з урахуванням випадків, що потребували пролонгованої ШВЛ) в післяопераційному періоді діагностовано у $3,0 \%$ хворих, оперованих без застосування ШК, у хворих із плановим призначенням ШК в 7,3\% випадках ( $p=0,023$ порівняно 3 групою КШ без застосування ШК) та у 13,4\% хворих 3 екстреним ШК (p<0,001 порівняно з групою КШ без застосування ШК та р >0,244 порівняно з групою з плановим ШК). Ниркову недостатність у групі хворих без застосування ШК діагностовано у 0,6\% випадків, при плановому застосуванні ШК - у 2,7\% ( $\mathrm{p}=0,039$ порівняно з групою КШ без застосування ШК); при екстреному застосуванні ШК - у 4,9\% хворих ( $<<0,001$ порівняно з групою КШ без застосування ШК та $p>0,05$ порівняно з групою з плановим ШК). Найбільш частим ускладненням післяопераційного періоду була миготлива аритмія, яку діагностовано у 18,1\% випадках у хворих без застосування ШК, при плановому засто- суванні ШК - в 20,9\% випадках (p>0,05 порівняно 3 групою КШ без застосування ШК) та у 22,0\% хворих 3 екстреним застосуванням ШК ( $>>0,05$ порівняно з групою КШ без застосування ШК та порівняно з групою $з$ плановим ШК). Післяопераційний інфаркт міокарда, пов'язаний із непрохідністю анастомозу, в групі хворих без застосування ШК діагностовано у 0,3\% хворих, при плановому ШК цього ускладнення не було, при екстреному застосуванні ШК післяопераційний інфаркт міокарда діагностований у 4,9\% хворих ( $<0,001$ порівняно з групою КШ без застосування ШК). Ранові та/або системні інфекційні ускладнення після операції діагностовано у $43(1,1 \%)$ хворих, яким виконано КШ без ШК, у 3,6\% хворих із плановим ШК (p=0,048 порівняно з групою КШ без застосування ШК) та у $9,8 \%$ у хворих з екстреним ШК ( $<0,001$ порівняно з групою КШ без застосування ШК та p >0,05 порівняно з групою з плановим ШК) (табл. 1).

В окремих випадках розвиток ускладнень призвів до фатальних наслідків - загалом померло 27 (0,7\%) хворих. У групі хворих без застосування ШК у ранньому післяопераційному періоді померло 19 (0,5\%) хворих. При плановому застосуванні ШК летальність склала 2,4\% (p>0,05 порівняно з групою КШ без застосування ШК), при екстреному застосуванні ШК летальність досягла 7,3\% ( $<0,001$ порівняно з групою КШ без застосування ШК та p>0,128 порівняно з групою із плановим ШК).

Отримані дані узгоджуються 3 результатами інших дослідників. Так, в університетському клінічному центрі м. Тузла (Боснія і Герцеговина) протягом 1998-2003 pp. було виконано 1000 операцій коронарного шунтування, у тому числі 49,3\% операцій були заплановані та виконувались із застосуванням ШК, $46,8 \%$ - без застосування ШК, та в 7,7\% випадків виконано екстрену конверсію на ШК. Частота інсультів після операції складала 1,8\%, 1,1\% та 10,3\% відповід- 
но, застосування аортального контрпульсатора $-0,8 \%$, 0,2\% та 7,7\% відповідно; частота ішемічних ускладнень становила 2,6\%, 1,3\% та 17,9\% відповідно [12]. У нещодавньому дослідженні J. Lim та співавт. (2017) у післяопераційному періоді в групі конверсії відмічено збільшення частоти ранніх ускладнень $(2,3 \%$ та $12,5 \%)$, пізньої смертності $(14,3 \%$ та $25,0 \%)$ та пізніх ускладнень (14,3\% та 18,8\%) [6]. При порівнянні результатів КШ на працюючому серці або із плановим чи екстреним застосуванням ШК встановлено, що кількість ускладнень протягом 30 днів після операції та у віддаленому періоді, післяопераційна летальність і летальність протягом тривалого спостереження були значно більшими в групі конверсії $[13,14]$. За даними Mukherjeе та співавт. (2011), розвиток інсульту, інфаркту міокарда, ниркової недостатності, кровотечі, що потребує повторного втручання, необхідність застосування внутрішньоаортальної балонної контрпульсації (ВАБК) та трансфузіі, дихальні та шлунково-кишкові ускладнення частіше пов'язані з конверсією [9].

Виявлені закономірності та результати досліджень інших авторів можна пояснити як негативним впливом ШК на перебіг післяопераційного періоду, так й більш важким вихідним станом пацієнтів, що потребує окремого аналізу.

У значній кількості випадків розвиток післяопераційних ускладнень був пов'язаний з інтраопераційними - нестабільною гемодинамікою, порушеннями серцевого ритму та ішемією міокарда, які найчастіше виникали під час позиціонування серця та формування анастомозів, а також із кровотечами і тромбозом шунтів на фоні значних патоморфологічних змін коронарних судин, внутрішньої грудної артерії та аорти.

Загалом клінічно значущі інтраопераційні ускладнення виникли у 10,4\% хворих. Найчастіше під час операції КШ виникала гемодинамічна нестабільність зі зниженням ефективності скоротливої функції серця з падінням системного артеріального тиску (АТ) та розвитком СН (вона зареєстрована у 7,0\% пацієнтів).

$\stackrel{\infty}{-}$ Слід зазначити, що в окремих випадках гемодинамічна нестабільність виникала в результаті порушень ритму та ішемії міокарда під час формування дистальних анастомозів. В інших хворих провідними залишалися ішемія міокарда (з елевацією сегмента ST на ЕКГ), що діагностована у 1,5\% хворих, та порушення ритму, зареєстровані у 1,3\% хворих. В 0,5\% випадків під час оперативного втручання виникли ускладнення з боку анастомозів у вигляді кровотечі та/або тромбозу шунта (табл. 2).

У 341 пацієнта (80,6\% від загальної кількості пацієнтів з інтраопераційними ускладненнями) ці ускладнення вдалося корегувати медикаментозно або технологічно (дефібриляція, зміна позиціонування хворого та ін.), але у $82(19,4 \%)$ випадків ці заходи були неефективними та потребували застосування допоміж-

\section{Таблиця 2}

Інтраопераційні ускладнення у пацієнтів, що ввійшли в дослідження

\begin{tabular}{lccc}
$\begin{array}{l}\text { Інтраопераційні } \\
\text { ускладнення }\end{array}$ & $\begin{array}{c}\text { КШ без ШК } \\
(\mathbf{n = 3 8 7 6 )}\end{array}$ & $\begin{array}{c}\text { КШ з екс- } \\
\text { трним ШК } \\
(\mathbf{n = 8 2 )}\end{array}$ & $\begin{array}{c}\text { Разом } \\
(\mathbf{n}=4068)\end{array}$ \\
\hline $\begin{array}{l}\text { Нестабільна } \\
\text { гемодинаміка }\end{array}$ & $233(6,0 \%)$ & $52(63,4 \%)$ & $285(7,0 \%)$ \\
\hline $\begin{array}{l}\text { Порушення } \\
\text { ритму }\end{array}$ & $40(1,0 \%)$ & $13(15,9 \%)$ & $53(1,3 \%)$ \\
\hline $\begin{array}{l}\text { Елевація сег- } \\
\text { мента SТ }\end{array}$ & $48(1,2 \%)$ & $15(18,3 \%)$ & $63(1,5 \%)$ \\
\hline Кровотеча & $20(0,5 \%)$ & $2(2,4 \%)$ & $22(0,5 \%)$ \\
\hline Всього & $341(8,8 \%)$ & $82(100 \%)$ & $423(10,4 \%)$
\end{tabular}

Примітка. Результати перевірки статистичної достовірності структури ускладнень наведено у тексті

ного ШК. В цій групі пацієнтів в 63,4\% випадків спостерігалася нестабільна гемодинаміка, в 15,9\% - порушення ритму, в 18,3\% - елевація сегмента ST та в $2,4 \%$ - кровотеча. У структурі окремих інтраопераційних ускладнень найбільш часто допоміжного ШК вимагали порушення ритму - $13(24,5 \%)$ з 53 випадків та

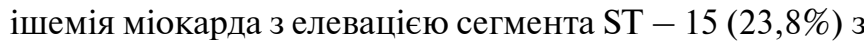
63 випадків. При нестабільній гемодинаміці екстрений перехід на ШК застосовано в 52 (18,2\%) з 285 випадків, при кровотечах екстрений ШК застосовано в $2(8,4 \%)$ з 22 випадків.

У групі хворих з екстреним ШК інтраопераційні ускладнення спостерігалися в усіх випадках. Саме вони й були підставою для підключення допоміжного ШК, у тому числі у $52(63,4 \%)$ хворих з 82 це була нестабільність гемодинаміки, у 13 (15,9\%) - порушення ритму, у $15(18,3 \%)$ - елевація сегмента ST та у $2(2,4 \%)$ - кровотеча. Тобто суттєвих відмінностей структури ускладнень між хворими, що перенесли КШ без ШК, і групою хворих з інтраопераційними ускладненнями, що вимагали конверсії на ШК, не виявлено (p>0,05 при порівнянні частоти усіх ускладнень).

Крім того, виникнення цих ускладнень в обох групах хворих спостерігалося у подібних обставинах: в окремих випадках при забезпеченні операційного доступу (стернотомії, перикардіотомії, накладанні тримачів і позиціонуванні серця), під час формування дистальних анастомозів (найчастіше на огинаючій гілці ЛКА, задній міжшлуночковій гілці та латеральній гілці ПКА, рідше на a.intermedia) та під час тимчасового затискання КА для накладання дистального анастомозу.

Подібні результати отримані й іншими дослідниками. Гемодинамічна нестабільність визначається як найпоширеніша причина конверсії [15]. E. Mujanović та співавт. (2008) повідомляють, що причиною конверсії була гемодинамічна нестабільність у 28 (71,8\%) 
випадках і технічні фактори в $11(28,2 \%)$ випадках (у тому числі інтрамуральне розташування судин, дрібні судини або потреба в ревізії анастомозу). На думку авторів, конверсія у зв'язку з технічними труднощами без суттєвої гемодинамічної нестабільності не спричиняє серйозних проблем. Гемодинамічна нестабільність зазвичай виникає при наявності вихідної ішемії або ішемії внаслідок навантаження під час позиціонування серця. Автори вважають, що ці випадки є результатом недооцінки ішемії міокарда під час планування операції [12]. Навіть короткочасна ішемія міокарда супроводжується зміною його метаболізму, що при відновленні кровотоку може призвести до реперфузійних ушкоджень міокарда [7]. Крім цього, на думку Y. Takami та співавт. (2014), тимчасова ішемія в басейні ПКА може бути причиною розладів ритму, включаючи атріовентрикулярний блок [8].

Слід зазначити, що в публікаціях інших авторів при визначенні причин екстреного переходу на ШК розглядаються саме інтраопераційні ускладнення, відтак подальша методологія у визначенні предикторів цих випадків полягає в аналізі тільки випадків із застосуванням екстреної конверсії на ШК на противагу плановому ШК або КШ без ШК. Як свідчать отримані нами результати, у хворих, у яких КШ завершено без допоміжного кровообігу, також спостерігаються схожі інтраопераційні ускладнення. Тому ми вважаємо перспективним подальше дослідження факторів ризику інтраопераційної конверсії на ШК з урахуванням хворих, у яких також виникли інтраопераційні ускладнення, що були усунені без застосування ШК.

\section{Висновки}

1. У хворих із застосуванням ШК (як планового, так й екстреного) спостерігається достовірне збільшення частоти СН, ДН, ниркової недостатності та інфекційних ускладнень.

2. У групі хворих з екстреним ШК достовірно частіше післяопераційний період був ускладнений IM, достовірно частіше виникала післяопераційна $\mathrm{CH}$ і була достовірно більша післяопераційна летальність порівняно з хворими без застосування ШК, але не достовірна порівняно з плановим застосуванням ШК.

3. Найбільш частою причиною екстреної конверсії на ШК під час реваскуляризації міокарда є гемодинамічна нестабільність, рідше трапляється елевація сегмента ST та порушення ритму.

4. Подібні інтраопераційні ускладнення виявлялися і в інших хворих, але вони були усунені без застосування допоміжного ШК. Можна припустити, що в усіх випадках інтраопераційних ускладнень вони мають подібні провокуючі фактори, що потребує подальшого аналізу.
5. Передопераційне визначення предикторів інтраопераційних ускладнень, що є причиною екстреної конверсії на ШК, є шляхом до поліпшення безпосередніх результатів реваскуляризації міокарда.

\section{Література}

1. Гандзюк В. А. Аналіз захворюваності на ішемічну хворобу серця в Україні / В. А. Гандзюк // Український кардіологічний журнал. - 2014. - № 3. - С. 45-52.

2. Коронарное шунтирование у пожилых пациентов / Тунгусов Д. С., Чернов И. И., Уртаев Р. А. [и др.] // Анналы хирургии. - 2012. - № 2. - С. 51-56.

3. Руденко А. В., Урсуленко В. И., Купчинский А. В. 10 тысяч операций коронарного шунтирования на работающем сердце (опыт одной клиники) // Вісник серцево-судинної хірургії - 2016. - Вип. 1.

4. Теренда Н. О. Основні тенденції та прогнозні оцінки загальної та первинної захворюваності на ішемічну хворобу серця в Україні / Н. О. Теренда // Вісник соціальної гігієни та організації охорони здоров'я України. -2016 . - № 3 (69). - С. 31-35.

5. 2014 ESC EACTS Guidelines on myocardial revascularization. The Task Force on Myocardial Revascularization of the European Society of Cardiology (ESC) and the European Association for Cardio-Thoracic Surgery (EACTS) Developed with the special contribution of the European Association of Percutaneous Cardiovascular Interventions (EAPCI) / Windecker S., Kolh P., Alfonso F. et al. // European Heart Journal. - 2014. - Vol. 35. - P. 2541-2619.

6. Analysis of Risk Factors for Conversion from Off-Pump to On-Pump Coronary Artery Bypass Graft / J. Lim, W. Y. Lee, Y. J. Ra [et al.] // Korean J ThoracCardiovasc Surg. - 2017. - Vol. 50. - P. 14-21.

7. Beneficial effects of ischemic preconditioning on right ventricular function after coronary artery bypass grafting / Z. K. Wu, M. R. Tarkka, E. Pehkonen [et al.] // Ann. Thorac. Surg. - 2000. - Vol. 70. - P. 155-157.

8. Clinical validation of coronary artery flow through an intracoronary shunt during off-pump coronary artery bypass grafting / Y. Takami, K. Tajima, W. Kato [et al.] // J ThoracCardiovasc Surg. - 2014. - Vol. 147 (1). - P. 259-263.

9. Conversion and safety in off-pump coronary artery bypass: a system failure that needs re-emphasis / Mukherjee D., Ahmed K., Baig K. [et al.] // Ann. Thorac. Surg. - 2011. Vol. 91. - P. 630-639.

10. Global, regional, and national life expectancy, all-cause mortality, and cause-specific mortality for 249 causes of death, 1980-2015: a systematic analysis for the Global Burden of Disease Study 2015 // Lancet. - 2016. - Vol. 388. P. $1459-1544$.

11. Legare J.-F., Buth K. J., Hirsch G. M. Conversion to on pump from OPCAB is associated with increased mortality: results from a randomized controlled trial // European Journal of Cardio-thoracic Surgery. - 2005. - Vol. 27. P. 296-301.

12. Managament of conversions to cardiopulmonary bypass in beating heart coronary surgery / E. Mujanović, J. Bergsland, S. Stanimirović-Mujanović, E. Kabil // Bosnian journal of basic medical sciences. - 2008. - Vol. 8 (3). - P. 266-269. 
13. Morbidity and mortality following acute conversion from offpump to on-pump coronary surgery / Reeves B. C., Ascion e R., Caputo M. [et al.] // Eur J Cardiothorac Surg. - 2006 Jun. - Vol. 29 (6). - P. 941-7.

14. Outcomes after conversion in the Veterans Affairs randomized on versus off bypass trial / Novitzky D., Baltz J. H.,
Hattler B. [et al.] // Ann Thorac Surg. - 2011. - Vol. 92. P. 2147-2154.

15. Predictors of emergency conversion to on-pump during offpump coronary surgery / A. Hovakimyan, V. Manukyan, S. Ghazaryan [et al.] // Asian CardiovascThorac Ann. 2008. - Vol. 16. - P. 226-230.

\title{
Causes and implications of emergency conversion on on-pump during coronary artery bypass grafting in patients with ischemic heart disease
}

\author{
Rudenko A. V., Zhurba O. O. \\ National M. M. Amosov Institute of Cardiovascular Surgery National Academy of Medical Sciences of Ukraine (Kyiv)
}

Emergency conversion on-pump during OPCABG significantly impairs the immediate results of myocardial revascularization. The purpose of this study was to review the causes and consequences of these cases based on the results of a retrospective analysis of 4,668 patients. It was established that in patients with the use of on-pump surgery, there is a significant increase of the frequency of all postoperative complications, and in case of emergency conversion postoperative lethality is increasing too. The reasons for emergency conversion were hemodynamic instability, elevation of the ST segment, and rhythm disturbances. These intraoperative complications were manifested in other patients, but they were eliminated without the use of on-pump surgery. We believe that the complications during the operation have similar provocative factors that should be taken into account when determining the predictors of their development.

Key words: coronary bypass, OPCABG, ONCABG, emergency conversion, immediate results, intraoperative complications.

\section{Причины и последствия экстренной конверсии на вспомогательное искусственное кровообращение при коронарном шунтировании у больных с ишемической болезнью сердца}

\author{
Руденко А. В., Журба О. А. \\ ГУ «Национальный институт сердечно-сосудистой хирургии имени Н. М. Амосова НАМН» (Киев)
}

Экстренная конверсия на ИК при КШ на работаюшем сердце значительно ухудшает непосредственные результаты реваскуляризации миокарда. Целью этого исследования был обзор причин и последствий этих случаев по результатам ретроспективного анализа историй болезни 4068 пациентов. Установлено, что у больных с применением ИК наблюдается достоверное увеличение частоты всех послеоперационных осложнений, а при экстренном ИК увеличивается послеоперационная летальность. Причинами экстренной конверсии были гемодинамическая нестабильность, элевация сегмента ST и нарушения ритма. Эти интраоперационные осложнения развивались и у других больных, но они были устранены без применения ИК. Считаем, что осложнения во время операции имеют подобные провоцирующие факторы, что следует учитывать при определении предикторов их развития.

Ключевые слова: коронарное шунтирование, работающее сердце, искусственное кровообращение, экстренная конверсия, непосредственные результаты, интраоперационные осложнения. 